Paedagogia Christiana

I/27 (201 I) - ISSN 1505-6872

Helena Stotwińska*

Lublin

\title{
Znaczenie kultury w wychowaniu chrześcijańskim
}

\begin{abstract}
Aby poszczególni ludzie wypełniali dokładniej swój obowiązek sumienia, czy to w stosunku do siebie, czy też w stosunku do różnych grup, których są członkami, trzeba ich starannie wychowywać ku pełniejszej kulturze duchowej, korzystając z ogromnych środków pomocniczych, stojących dziś do dyspozycji rodu ludzkiego. Przede wszystkim wychowanie młodzieży niezależnie od jej pochodzenia społecznego tak należy dziś prowadzić, by formowało mężczyzn i kobiety, którzy nie tylko byliby wykształceni, ale też i wielkoduszni, ponieważ nasze czasy gwałtownie domagają się tego (KDK 31)․․‥
\end{abstract}

Treścią niniejszego przedłożenia będzie najpierw wyjaśnienie pojęcia kultury, następnie kultura zostanie przedstawiona jako jedna z form udoskonalania świata i samego siebie. Ponadto $w$ artykule ukazany zostanie związek Bożego orędzia zbawienia a także wychowania chrześcijańskiego z kulturą.

\section{Pojęcie kultury}

Pojęcie kultury cechuje różnorodność ujęć. Podkreślił to J. G. Herder, pisząc przed prawie pół wiekiem, że „nie ma nic bardziej nieokreślonego niż

* Prof. dr hab. Helena Słotwińska jest kierownikiem Katedry Katechetyki Integralnej w Instytucie Teologii Pastoralnej i Katechetyki Katolickiego Uniwersytetu Lubelskiego Jana Pawła II.

${ }^{1}$ Konstytucja duszpasterska o Kościele w świecie współczesnym Gaudium et spes, w: Sobór Watykański II. Konstytucje. Dekrety. Deklaracje, Poznań 1968 - w tekście: KDK z odnośnym numerem. 
słowo «kultura»"2. Stownik kościelny tacińsko-polski słowo cultura thumaczy jako „opracowanie, uprawa roli, kultura leśna; cześć, religia; pielęgnowanie, kształcenie"’. W Slowniku wyrazów obcych, pojęcie «kultura» (łac. cultura - uprawa, kształcenie), jest thumaczone jako:

(1) materialny i duchowy dorobek ludzkości, wytworzony w rozwoju społeczno-historycznym; kultura duchowa - w danej epoce historycznej ogół osiagnięć społeczeństwa w nauce i sztuce, w organizowaniu życia społecznego i politycznego, w moralności i obyczajach; kultura materialna - ogół istniejących na danym etapie historycznym sił, środków i umiejętności produkcyjnych oraz nagromadzonych dóbr materialnych, (2) kultura archeologiczna - zespół znalezisk zabytków kultury materialnej z wczesnych epok, nazywany zazwyczaj od miejscowości, w której po raz pierwszy znaleziono dane zabytki (np. k. trypolska), albo od najbardziej charakterystycznych zabytków (np. k. pucharów lejkowatych), (3) stopień doskonałości osiagnnięty w opanowaniu tej lub innej gałęzi wiedzy czy działalności (np. k. pracy, k. jezzyka, k. fizyczna), (4) uprawa, hodowla ${ }^{4}$.

W naukach społecznych „kulturą” jest wszystko to w społeczeństwie ludzkim, co jest przekazywane raczej społecznie niż biologicznie, natomiast w języku potocznym przez „kulturę” rozumie się zwykle tylko sztukę. Zatem słowo «kultura» jest terminem ogólnym, określającym symboliczne i wyuczone aspekty społeczeństwa ludzkiego. Jednak niektórzy behawioryści, prowadzący badania zwierząt, twierdzą obecnie, że pewne naczelne dysponują co najmniej zdolnościami kulturowymi ${ }^{5}$.

Nowa encyklopedia powszechna PWN przy haśle «kultura» zaznacza najpierw, że jest to ,jeden z najbardziej popularnych terminów humanistyki i nauk społecznych, a także języka potocznego, w którym jednak ma zwykle inne znaczenie i silne zabarwienie wartościujące”. Następnie wyjaśnia, że

w znaczeniu najszerszym, kultura obejmuje to wszystko, co w zachowaniu się i wyposażeniu członków społeczeństw ludzkich stanowi rezultat zbiorowej działalności. Mówi się też o kulturze jako tym, co w zachowaniu się ludzkim jest wyuczone - w odróżnieniu od tego, co biologicznie odziedziczone. W zastosowaniu pierwotnym słowo cultura odnosiło się głównie do uprawy roli, dość wcześnie jednak zaczęło być stosowane metaforycznie (np. przez Cyce-

\footnotetext{
2 J. G. Herder, Myśli o filozofii dziejów, t. I, Warszawa 1962, s. 4.

3 A. Jougan, Stownik kościelny tacińsko-polski, Poznań-Warszawa-Lublin 1958, s. 167.

${ }^{4}$ Z. Rysiewicz (red.), Stownik wyrazów obcych, Warszawa 1967, s. 379.

${ }^{5}$ G. Marshall (red.), Stownik socjologii i nauk społecznych, Warszawa 2006, s. 165.
} 
rona, który pisał również o «kulturze duszy») do innych dziedzin, w których starania ludzkie prowadzą do poprawy stanu wyjściowego ${ }^{6}$.

Ziemia uprawiana przez człowieka osiaga stan lepszy, bardziej doskonały, bardziej użyteczny dla niego. Podobnie poddany „uprawie” - na przykład przez myślenie i kształcenie - rozum ludzki coraz bardziej się doskonali. Termin «kultura», używany przez całe stulecia tylko sporadycznie w znaczeniu metaforycznym, zyskał wielką popularność w wieku XVIII. I wówczas był on odnoszony do moralnego i umysłowego doskonalenia się człowieka. W wieku następnym pojęcie «kultura», używane zwykle zamiennie z pojęciem «cywilizacja», zdobyło bardzo szerokie zastosowanie. Oznaczano nim wówczas całokształt zarówno duchowego, jak i materialnego dorobku społeczeństwa. W wieku XX bardzo powszechna była tendencja do ujmowania kultury jako zespołu wzorów do rozwiązywania problemów charakterystycznych dla danego społeczeństwa, wzorów postępowania itp ${ }^{7}$.

O wyraźnym przeciwstawieniu kultury cywilizacji, którą uważa się za część kultury, uformowaną przez technikę, służącą zaspokajaniu potrzeb życiowych (̇̇ycia), pisze Leksykon pedagogiki religii. Najpierw podkreśla, że słowo «kultura» (łac. colere - budować, uprawiać) pierwotnie stosowano wyłącznie w odniesieniu do zjawisk przyrody. A następnie dodaje, że rzeczownik «kultura» w językach nowożytnych oznacza określony sposób przekształcania naturalnego środowiska i świata tworzonego przez ludzi oraz aktywne zachowanie się człowieka umożliwiające to przekształcanie. Następnie stwierdza, że „na całość kultury składa się [...] nauka, sztuka, religia i moralność, przy czym nauka wydaje się zajmować w niej szczególną pozycję. [...] Zmieniały się konstelacje społeczno-polityczne i religijne, ale strumień nauki nigdy nie wysechł, nawet wtedy, gdy wydawała się ona jedynie zbiorem pytań"s.

Sobór Watykański II spojrzał na kulturę w bardzo szerokim kontekście. W Dekrecie o apostolstwie świeckich Apostolicam actuositatem zapisano:

Wszystko, co składa się na porządek spraw doczesnych, mianowicie: dobra osobiste i rodzinne, kultura, sprawy gospodarcze, sztuka i zajęcia zawodowe, instytucje polityczne, stosunki międzynarodowe i inne tym podobne, rozwój ich i postęp, stanowi nie tylko pomoce do osiagnięcia przez człowieka celu ostatecznego, ale posiada też własną, wszczepioną im przez Boga wartość, czy

${ }^{6}$ B. Petrozolin-Skowrońska (red.), Nowa encyklopedia powszechna PWN, t. 3, Warszawa 1997, s. 618.

7 Tamże.

${ }^{8}$ S. Bafia, Kultura, w: C. Rogowski (red.) Leksykon pedagogiki religii, Warszawa 2007, s. 366 . 
to wzięte same w sobie, czy jako części całego porządku doczesnego: «I widział Bóg, że wszystko, co uczynił, było bardzo dobre» (Rdz 1, 31; DA 7)9.

Wyjaśniając natomiast znaczenie słowa «kultura», w Konstytucji duszpasterskiej o Kościele w świecie współczesnym Gaudium et spes Ojcowie Soborowi zapisali:

wyraz «kultura» oznacza wszystko, czym człowiek doskonali, rozwija wielorakie uzdolnienia swego ducha i ciała; stara się drogą poznania i pracy poddać sam świat pod swoją władzę; czyni bardziej ludzkim życie społeczne tak w rodzinie, jak i w całej społeczności państwowej przez postęp obyczajów i instytucji; w dziełach swoich w ciągu wieków wyraża, przekazuje i zachowuje wielkie doświadczenia duchowe i dążenia na to, aby służyły one postępowi wielu, a nawet całej ludzkości (KDK 53).

Z tej soborowej „definicji” kultury wynika, że kultura ludzka ma swój aspekt zarówno historyczny, jak i społeczny. Ponadto wyraz «kultura» przybiera nieraz znaczenie socjologiczne oraz etnologiczne, co z kolei stwarza możliwość do mówienia o wielości kultur.

Człowiek współczesny znalazł się w nowej epoce historii ludzkiej, w której stoją przed nim nowe możliwości udoskonalania i poszerzania zasięgu kultury. Stało się to dzięki ogromnemu wzrostowi nauk przyrodniczych, humanistycznych i społecznych, dzięki rozwojowi techniki i postępowi w wytwarzaniu i właściwym rozpowszechnianiu środków komunikowania się ludzi pomiędzy sobą (telefonia komórkowa, Internet). Powstają nowe formy kultury, a wśród nich między innymi kultura masowa. $\mathrm{Z}$ nich rodzą się nowe sposoby myślenia, działania i spędzania wolnego czasu. Dzięki rozwijającym się relacjom pomiędzy różnymi narodami i stowarzyszeniami społecznymi, otwiera się dla każdego człowieka szerszy dostęp do skarbów różnych form kultury. W ten sposób przygotowuje się bardziej powszechna forma ludzkiej kultury, która uwzględniając odrębność różnych kultur, równocześnie wyraża jedność rodzaju ludzkiego (por. KDK 54).

\section{Kultura jedną z form udoskonalania świata}

Biblijny opis stworzenia świata ukazuje stworzenie człowieka jako ostatnie dzieło Bożych rąk. W ten sposób Autor biblijny przekazał prawdę, że

${ }^{9}$ Dekret o apostolstwie świeckich Apostolicam actuositatem, w: Sobór Watykański II, w tekście DA z odnośnym numerem. 
człowiek jest ukoronowaniem całego dzieła stwórczego, które zostało dopełnione dzięki powołaniu go do bytu. Ten biblijny zapis potwierdza prawdę, że Bóg dla człowieka stworzył cały świat. I w ten sposób Bóg przygotował dla niego - zanim go stworzył - przede wszystkim mieszkanie.

Prawda o wielkiej godności człowieka została jeszcze bardziej uwydatniona słowami określającymi związek człowieka z Bogiem: „Stworzył więc Bóg człowieka, na obraz Boży go stworzył: stworzył mężczyznę i niewiastę" $(\operatorname{Rdz} 1,27)$. Prawda o podobieństwie człowieka do Boga może być rozważana na wielu płaszczyznach. Przede wszystkim człowiek, jako istota rozumna i wolna, jest podobny do Boga. Obie te wartości wynoszą człowieka ponad świat i czynią go razem z Bogiem - Stwórcą świata, królem i panem wszechświata. Niezwykłą godność człowieka jeszcze bardziej podkreśla drugi opis stworzenia człowieka (por. Rdz 2, 7nn.). Cały szereg zamieszczonych tutaj obrazów nie tylko podkreśla prawdę, że człowiek otrzymał rozum i wolną wolę, ale także ukazuje, że Bóg Stwórca wiąże się z człowiekiem łaską niezwykłej przyjaźni, ubogaconej w nadzwyczajne dary nieśmiertelności, niezwykłej wiedzy oraz nieskazitelności ${ }^{10}$.

Ukazanie stworzenia świata, jako dzieła, nad którym Bóg pracował (por. Rdz 2, 2), upoważnia do stwierdzenia, że człowiek, stworzony na obraz Boga, został stworzony jako człowiek pracy. Ponadto za takim tłumaczeniem przekazu biblijnego o człowieku, jako „obrazie Boga”, przemawia polecenie wraz z Bożym błogosławieństwem, aby ludzie przez niego stworzeni, jako małżonkowie nie tylko zadbali o powołanie dzieci do życia, ale by także udoskonalali świat: „Bóg im błogosławił, mówiąc do nich «Bądźcie płodni i rozmnażajcie się, abyście zaludnili ziemię i uczynili ją sobie poddaną; abyście panowali nad rybami morskimi, nad ptactwem powietrznym i nad wszystkimi zwierzętami pełzającymi po ziemi»” ( $\mathrm{Rdz} 1,28)$. W ten sposób świat stworzony przez Boga Stwórcę - w stanie pierwotnym - został przekazany człowiekowi, jako twórcy, aby go udoskonalał. Zatem już wtedy człowiek otrzymał zadanie tworzenia kultury. Dlatego od tego czasu wszelka praca moralnie dobra, bez względu na rangę, jest udoskonalaniem świata stworzonego przez Boga. Będąc zaś równocześnie wykonywaniem Bożego nakazu, realizacją woli Bożej, przybiera wartość modlitwy - autentycznej rozmowy z Bogiem. Włącza się bowiem w dialog prowadzony przez Boga ze stworzeniem. Jest także pozytywną odpowiedzią na słowo Boga. Ta ludzka odpowiedź przybiera różne formy: jest to praca fizyczna, umysłowa, odkrywcza, praca nad sobą - wychowywanie samego siebie, praca wychowawcza obejmująca innych.

${ }^{10}$ S. Łach (red.), Pismo Święte Starego Testamentu, t. I, cz. 1: Księga Rodzaju. Wstępprzekład z oryginatu - komentarz, Poznań 1962, s. 178. 
Należy jeszcze raz podkreślić, że każda praca moralnie dobra jest nakazanym przez Boga udoskonalaniem świata. Otrzymany świat człowiek ma przeobrażać i czynić go sobie poddanym. A czyni to dokonując wielkich odkryć, ale także korzystając z wszelkich dostępnych mu osiągnięć techniki. Ważne jednak jest, aby nie być tylko konsumentem wysiłku innych. Każdy powinien czuć się odpowiedzialny za wniesienie w udoskonalanie świata tyle, na ile go stać. Może to być nawet bardzo mały wkład, ale powinien on być.

\section{Kultura jedną $\mathrm{z}$ form udoskonalania samego siebie}

„Jest właściwością osoby ludzkiej, że do prawdziwego i pełnego człowieczeństwa dochodzi ona nie inaczej jak przez kulturę, to znaczy przez kultywowanie dóbr i wartości naturalnych. Gdziekolwiek więc chodzi o sprawy życia ludzkiego, tam natura i kultura jak najściślej wiążą się ze sobą" (KDK 53).

Człowiek twórca, udoskonalający świat dany mu przez Boga Stwórcę, tworzy kulturę, a równocześnie sam jest nośnikiem kultury - ikoną kultury, udoskonalając samego siebie. Wspomniane wyżej teksty biblijne mówią o wielkiej godności człowieka. Staje się przedmiotem podziwu dla Psalmisty, który po wypowiedzeniu pochwały pod adresem Boga Stwórcy, zwraca się do Niego z pytaniem: „O Panie, nasz Boże... czym jest człowiek, że o nim pamiętasz... Uczyniłeś go niewiele mniejszym od istot niebieskich, chwałą i czcią go uwieńczyłeś. Obdarzyłeś go władzą nad dziełami rąk Twoich; złożyłeś wszystko pod jego stopy: owce i bydło wszelakie, a nadto i polne stada, ptactwo powietrzne oraz ryby morskie, wszystko, co szlaki mórz przemierza" (Ps 8, 1. 5. 6-9).

Z przytoczonego psalmu jasno wynika, że najwyższą rangę wśród całego stworzenia zajmuje człowiek, że on jest koroną całego stworzenia i że całe dzieło Bożych rąk zostało złożone pod jego stopy, wynika także obowiązek udoskonalania samego siebie. Chodzi tutaj zarówno o intelektualny rozwój człowieka, o zdobywanie wiedzy o świecie, jak i o jego moralny posęp.

Człowiek jako osoba nie jest istotą raz na zawsze określoną i pełną, ale jest istotą ciągle stającą się, istotą zdążającą do swojej pełni. Staje się on coraz bardziej człowiekiem dzięki trwającej w jego wewnętrznym życiu potężnej walce o prawdę, dobro i piękno, a także o inne wartości (np. wolność, sprawiedliwość, honor, dobre imię, sławę, równość, braterstwo, przyjaźń, pokój duchowy, moralność, kulturę duchową, wiedzę, sztukę itd.). Kształt osoby to zatem realny układ wartości i antywartości, pozostających ze sobą w ogromnym napięciu i śmiertelnej walce. 
Nie ma osoby, czy to indywidalnej, czy społecznej, bez wolności. Wolność określa się w ogólności jako realną możność własnego spełniania się osoby w aspekcie indywidualnym i społecznym. Wolność posiada różne postacie, z których najbardziej fundamentalnymi są: wolność wyboru (ma trzy postacie: wolność działania, wolność moralną i wolność wyboru środków wolność „specyfikacji”), wolność egzystencjalna (wolność istnienia, życia, bytowania i samorealizacji), wolność prozopoiczna, będąca możnością wewnętrznej i zewnętrznej realizacji człowieka jako osoby na wszystkich płaszczyznach (duszy, ciała, umysłu, woli; ma ona wymiar indywidualny i społeczny), wolność ontologiczna i strukturalna, która jest warunkiem koniecznym, żeby coś było rzeczywiste. Wolność jest tak ważna, że bez wolności nie ma bytu. Stąd dawne określenie człowieka jako animal rationale trzeba uzupełnić określeniem: et liberum (homo est animal rationale et liberum) ${ }^{11}$.

Najważniejszą czynnością w procesie „stawania się” osobą jest dialog. W nurcie personalistycznym zdecydowanie zaznacza się tzw. personalizm dialogiczny. Kierunek ten definiuje osobę z punktu widzenia jej odniesienia do drugiej osoby - jako «ja» pozostające w relacji do «ty». Osoba zatem ma strukturę względnie egzystencję dialogiczną, tzn. że znajduje swoją granicę w drugiej osobie - moje «ja» jest określone przez jakieś «ty». I dopiero w obliczu jakiegoś «ty» osoba przeżywa siebie jako «ja», względnie posiada siebie w obliczu granicy, jaką stanowi «ty» drugiej osoby. Ta druga osoba, to jakieś «ty», stanowi dla mojego «ja» punkt odniesienia, który pozwala mi określić siebie.

Znany „filozof dialogu” Martin Buber (1878-1965) stwierdza, że „człowiek staje się «Ja» w kontekście «Ty»”. I zarzuca Heideggerowi, że utworzył abstrakcyjny, a nie autentyczny obraz człowieka. Tymczasem istota ludzka nie jest zwrócona ku sobie - jak chce Heidegger - ale ku innym. Bez powiązania z kimś «Drugim» (Bogiem i ludźmi) nie jest w ogóle człowiekiem. Zatem istotę ludzką widzi właściwie tylko ten, kto ujmuje ją w relacjach do Boga i świata, a nie w izolacji od rzeczywistości. Człowiek do tego stopnia jest istotą dialogiczna, że relacje «Ja» - «Ty» są osobotwórcze. Podstawą jednak wszelkiego dialogu jest «Boskie Ty», ujmowane podmiotowo, które nigdy nie może stać się przedmiotem. Dialog z ludźmi bez Boga i odwrotnie jest rzeczą niemożliwą. W relacji dialogowej wytwarza się jakaś sfera łącząca obydwa podmioty, którą można nazwać «Między» (Zwischen). Nie jest ona żadną konstrukcją pomocniczą, lecz jest rzeczywistym miesjcem, które nosi ludzkie „stawanie się"12.

11 Cz. S. Bartnik, Personalizm, Lublin 2000, s. 295.

12 M. Buber, Ja i Ty. Wybór pism filozoficznych, Warszawa 1992, s. 56; J. Tarnowski, Martin Buber - nauczyciel dialogu, ,Znak” 32 (1980), nr 7 (313), s. 867-874. 
Ogromnie ważna dla każdej osoby jest zdolność „wyjścia” z siebie, by spotkać się z drugą osobą i by wejść z nią w dialog, udzielając się sobie nawzajem. Człowiek bowiem staje się w pełni osobą dopiero we wzajemnym dawaniu i przyjmowaniu siebie. Zatem osoba ze swojej istoty skierowana jest do dialogu i dopiero w spotkaniu z drugą jednostką może realizować swoją osobowość. Będąc przeznaczoną do dialogu, osoba ma strukturę dialogiczną.

Należy jednak podkreślić, że ten dialogiczny, a w wymiarze szerszym społeczny charakter osoby ludzkiej nie może być rozumiany jako ,utracenie” lub ,zagubienie” własnej osobowości, tożsamości czy podmiotowości. Wprost przeciwnie, im bardziej człowiek chce wchodzić w dialog z innymi, otwierać się na innych i dawać im siebie, tym bardziej powinien poznać siebie i mieć siebie, być panem samego siebie (opanować siebie), odkryć własną tożsamość. Stara zasada filozoficzna bowiem głosi, że nie można dać tego, czego się nie posiada (nemo dat, quod non habet). To poznawanie siebie, zgłębianie prawdy o sobie i odkrywaie własnej tożsamości dokonuje się w trudzie i mozole, ale jest rzeczą niezbędną w procesie „stwania się" pełnym człowiekiem.

\section{Związek Bożego orędzia zbawienia z kulturą}

„Pomiędzy orędziem zbawienia a kulturą ludzką istnieją wielorakie powiązania. Bóg bowiem, objawiając się swemu ludowi aż do pełnego okazania się w Synu Wcielonym, przemawiał stosownie do stanu kultury właściwego różnym epokom" (KDK 58). Bóg bowiem, zanim przemówił przez swojego Syna, wpierw przemawiał przez ludzi, na sposób ludzki ${ }^{13}$. I dlatego, komentator Pisma Świętego, chcąc poznać właściwą treść Bożego objawienia, powinien badać rodzaje literackie używane w tamtych czasach, którymi hagiografowie oddali Boże prawdy. Należy także uwzględnić zwyczaje, naturalne sposoby myślenia, mówienia i opowiadania, przyjęte w czasach hagiografa, a także sposoby, jakie stosowano w tamtej epoce przy wzajemnym komunikowaniu się ludzi ze sobą. Ponadto, dla wydobycia właściwego sensu świętych tekstów należy uwzględnić treść i jedność całej Biblii w świetle żywej Tradycji całego Kościoła oraz analogii wiary. Ostateczny jednak sposób interpretacji tekstów biblijnych podlega osądowi Magisterium Ecclesiam (por. KO 12) ${ }^{14}$. Rozważając niniejszy problem należy podziwiać

${ }_{13}$ Por. Św. Augustyn, De Civit. Dei. XVII. 6, 2: PL 41,537; CSEL 40, 2, 288.

${ }^{14}$ Konstytucja dogmatyczna o Objawieniu Bożym Dei Verbum, w: Sobór Watykański II, w tekście DO z odnośnym numerem. 
niezwykłą dobroć Boga, który w mowie tak bardzo dostosował się do natury ludzkiej i jej sposobu wyrażania Bożych prawd. „Słowa Boże, językami ludzkimi wyrażone, upodobniły się do mowy ludzkiej, jak niegdyś Słowo Ojca Przedwiecznego, przyjąwszy słabe ciało ludzkie, upodobniło się do ludzi" (KO 13).

Kościół zatem w swoim nauczaniu zdecydowanie podkreśla, że nie można dawnych utworów obecnych w Biblii oceniać na podstawie kryteriów historiografii współczesnej, lecz należy na nie spojrzeć na tle analogicznej literatury mezopotamskiej, stanowiącej dorobek tamtejszej kultury. Dla ilustracji warto przypomnieć, że poematowi o stworzeniu świata, zawartemu w Biblii (Rdz 1, 1-2, 4a), odpowiada wzięty z kultury babilońskiej poemat Enuma elis, a odpowiednikiem opowiadania biblijnego o potopie ( $\mathrm{Rdz} 6$, $1-9,17)$ jest poemat babiloński o przygodach Gilgamesza, króla starożytnego miasta Uruk w południowej Babilonii. Także opowiadanie o raju, o pierwotnej szczęśliwości człowieka, utraconej przez grzech ( $\operatorname{Rdz} 2,4 \mathrm{~b}-3,24)$, genealogie patriarchów biblijnych (sprzed potopu i po potopie), a także opowiadanie o wieży Babel, wykazują duże podobieństwo z literaturą babilońską. Należy wziąć pod uwagę fakt, że autor biblijny to pisarz religijny, a nie prehistoryk, geolog czy paleontolog. Jego celem nie było podawanie prawd z tych dziedzin naukowych, ale podanie ludzkości fundamentalnych prawd objawienia Bożego, takich jak: stworzenie świata przez Boga, powołanie do istnienia pierwszej pary ludzkiej (mężczyzny i kobiety) przez szczególną interwencję Bożą, pochodzenie całej ludzkości od tej jednej pary, stan jej doskonałości moralnej i szczęśliwości oraz jej upadek i zgubne jego następstwa zarówno dla niej samej, jak i dla jej potomstwa. Przekazując te prawdy, autor biblijny przybrał je w taką szatę, jaka była dostępna i zrozumiała dla izraelskich adresatów, którzy czerpali z kultury ludów żyjących w Mezopotamii. To tłumaczenie staje się tym bardziej wiarygodne, że przecież przodkowie Hebrajczyków wyszli z Mezopotamii, gdzie mieszkał przez jakiś czas ich praojciec Abraham ${ }^{15}$. Podziwu godna jest tutaj Boża pokora i mądrość objawiająca się w Bożej pedagogii. Bóg - Twórca ludzkiej natury - znając dorobek ludzkości w dziedzinie kultury w określonej epoce, pozwala, aby Jego wielkie prawdy były przekazywane przy pomocy prymitywnych w oczach ludzi innej epoki obrazów.

Należy podkreślić, że Lud Boży Starego Testamentu, odznaczając się mentalnością bardzo konkretną, chcąc mówić o Bogu transcendentnym, musiał odwoływać się do rzeczywistości ziemskich. Antropomorfizmy, bardzo liczne w pierwotnych tekstach, to symbole, które zawierały w sobie pierwsze sformułowania przypowieści. Takim jest tekst biblijny o ulepieniu człowieka

${ }^{15}$ S. Łach (red.), dz. cyt., s. 147 nn. 
przez Boga z prochu ziemi i przekazaniu mu tchnienia życia oraz o pierwotnym stanie jego szczęścia, a także o ulepieniu zwierząt i ptaków, o nadawaniu im imion, o stworzeniu niewiasty z żebra pierwszego człowieka (por. Rdz 2, 7n. 19. 21n.). Życie człowieka, a zwłaszcza jego aspekt moralny i religijny, domagało się stosowania różnych przypowieści. Stąd też prorocy bardzo często posługują się nimi. Czynią to zarówno wtedy, gdy potępiają błędy ludzkie (por. Am 4, 1; Oz 4, 16; Iz 5, 18), jak i wówczas, gdy przekazują obietnice Boże (por. Oz 2, 20n; Iz 11, 6-9; Jer 31, 21). Ponadto bardzo chętnie posługują się działaniem symbolicznym, czyli nauczają za pomocą pewnych akcji (por. Iz 20, 2; Jer 19, 10; Ez 4-5). Ilustrując sens historii świętej za pomocą rzeczywistości z ludzkiego życia, prorocy tworzą specjalne tematy, a mianowicie: Pasterz, owca, owczarnia, małżeństwo, winnica ${ }^{16}$. Właściwie cały Stary Testament obfituje w metafory, aforyzmy, przysłowia, zagadki oraz inne obrazowe mowy, a także w przypowieści w formie krótkiego opowiadania z podwójnym znaczeniem, będące wytworem kultury określonej epoki ${ }^{17}$. Należy do nich na przykład Pieśn o winnicy ${ }^{18}$ czy opowiadanie proroka Natana o bogaczu, który zabrał owieczkę biedakowi ${ }^{19}$. W Pieśni o winnicy słuchacze zostali wyraźnie zaproszeni do aktywnego uczestnictwa w tym opowiadaniu ${ }^{20}$. Podobnie reakcja Dawida na obraz z przypowieści Natana wyraźnie wskazuje, że król dogłębnie uczestniczył w tym opowiadaniu proroka. Warto dodać, że w każdym przypadku do przypowieści została dołączona jej interpretacja ${ }^{21}$.

Jezus Chrystus - ostatnie Słowo Ojca wypowiedziane do ludzkości, wyjątkowo trudne prawdy podaje w przypowieściach ${ }^{22}$. Na szczególną uwagę

${ }^{16}$ D. Sesboüe, Przypowieść, w: X. Leon-Dufour (red.), Stownik teologii biblijnej, Poznań-Warszawa 1973, s. 833-834.

17 J. D. Crossan, Przypowieści, w: P. J. Achtemeier (red.), Encyklopedia biblijna, Warszawa 1999, s. 1022.

${ }^{18}$ Zob. Iz 5, 1-2.

${ }_{19}$ Zob. 2 Sm 12, 1-4.

${ }^{20}$ Zob. Iz 5, 3-4.

${ }^{21}$ Zob. Iz 5, 7; 2 Sm 12, 7-9.

${ }^{22}$ Są to: przypowieść o ziarnku gorczycy (Mt 13, 31-32; Mk 4, 30-32; Łk 13, 18-19), o siewcy (Mt 13, 3-8; Mk 4, 3-8; Łk 8, 5-8), o przewrotnych rolnikach (Mt 21, 3-42; Mk 12, 1-11; Łk 20, 9-18), o zasiewie (Mk 4, 26-29), o zaczynie (Mt 13, 33; Łk 13, 20-21), o uczcie królewskiej (Mt 22, 1-4; Łk 14, 16-24), o zaginionej owcy (Mt 18, 12-13; Łk 15, 4-6), o talentach (Mt 25, 14-30; Łk 19, 11-27), o pszenicy i chwaście (Mt 13, 24-30), o skarbie (Mt 13, 44), o perle (Mt 3, 44-46), o sieci (Mt 13, 47-48), o bogatym głupcu (Lk 12, 16-20), o nielitościwym dłużniku (Mt 18, 23-24), o robotnikach w winnicy (Mt 20,1-15), o dziesięciu pannach (Mt 25, 1-12), o dobrym Samarytaninie (Łk 10,30-35), o nieurodzajnym drzewie figowym (Łk 13, 6-9), o budowniczym wieży (Łk 14, 28-30), o królu wyruszającym na wojnę (Łk 14, 31-32), o zagubionej drachmie (Łk 15, 8-9), o synu marnotrawnym (Łk 15, 11-32), 
zasługują przypowieści o Królestwie Bożym (por. Mt 13, 1-50; 20, 1-16; 21, $33-22,14 ; 24,45-25,30)$. Niektóre Chrystusowe przypowieści zawierają nie tylko ogólne pouczenie, ale także każdy element ich pouczenia ma swoje własne znaczenie i wówczas przypowieści te przyjmują charakter alegorii. Taką właściwość ma zwłaszcza przypowieść o dobrym Pasterzu (por. J 10, 1-16), o winnym krzewie i o latorośli (por. J 15, 1-6). Ten alegoryczny charakter niektórych przypowieści ewangeliści specjalnie akcentują, sugerując równocześnie pewną jego interpretację. Tak czyni na przykład św. Mateusz, który alegorycznego „Pana waszego”, widzi w „Panu domu”, o którym Jezus mówił w przypowieści o potrzebie czujności (por. Mt 24, 42; Mk 13, 35). Ewangelista Marek po przedstawieniu przypowieści o siewcy, lampie, mierze, zasiewie i o ziarnku gorczycy ${ }^{23}$, chcąc jednak podkreślić, że nie były to wszystkie przypowieści w nauczaniu Chrystusa, na podsumowanie tego zagadnienia napisał: „W wielu takich przypowieściach głosił im naukę o ile mogli (ja) rozumieć. A bez przypowieści nie przemawiał do nich. Osobno zaś objaśniał wszystko swoim uczniom" (Mk 4, 33-34). Postawy niektórych osób wprowadzonych do przypowieści mogą szokować, na przykład obrotnego rządcy, który trwonił majątek swego pana ${ }^{24}$, albo sędziego, „który Boga się nie bał i nie liczył się z ludźmi”'25. Ważne przy tym jest, aby w każdej prawie przypowieści wzią́ pod uwagę najpierw aspekt teocentryczny lub chrystocentryczny. Nie ulega wątpliwości, że główna postać danej przypowieści najczęściej przedstawia osobę Boga Ojca ${ }^{26}$ albo Syna Bożego, Jezusa Chrystusa $^{27}$. Jeżeli natomiast $\mathrm{w}$ przypowieści występują dwie postacie, to wówczas chodzi zarówno o Boga Ojca, jak i Syna Bożego ${ }^{28}$.

\section{Wychowanie chrześcijańskie a kultura}

To powiązanie orędzia zbawienia z kulturą ludzką, obecne już na pierwszych kartach Pisma Świętego, wyraźnie wskazuje na konieczność powią-

o obrotnym rządcy (Łk 16, 1-8a), o bogaczu i Łazarzu (Łk 16, 19-31), o niesprawiedliwym sędzim (Łk 18, 2-5), o faryzeuszu i celniku (Łk 18, 10-13).

${ }^{23}$ Zob. Mk 4, 1-20; 21-23; 24-25; 26-29; 30-32.

${ }^{24}$ Zob. Łk 16, 1-8.

${ }^{25}$ Zob. Łk 18, 1-5.

${ }^{26}$ Zob. Mt 21, 28n: Przypowieść o dwóch synach; Łk 15, 11 nn: Przypowieść o synu marnotrawnym.

27 Zob. Mt 13, 3nn: Przypowieść o siewcy; 24, 42-44: Potrzeba czujności (o złodzieju); 25, 1-13: Przypowieść o pannach roztropnych i nierozsądnych; 25, 14nn: Przypowieść o talentach.

${ }^{28}$ Zob. Mt 20, 1-16: Przypowieść o robotnikach winnicy; 21, 33-46: Przypowieść o przewrotnych rolnikach; 22, 1-14: Przypowieść o uczcie królewskiej. 
zania z kulturą również wychowania chrześcijańskiego. Człowiek jest istotą która posiada zdolność rozwijania i kształtowania siebie we współpracy z ludźmi i z Bogiem. Wychowanie człowieka jest właśnie kształtowaniem w znaczeniu doskonalenia go we wszystkich dziedzinach jego życia i działalności, czyli kształtowaniem osoby ${ }^{29}$. Jest to

całokształt zabiegów, mających na celu uformować człowieka pod względem fizycznym, moralnym, religijnym i umysłowym oraz przygotowanie go do życia wśród innych: w rodzinie, w ojczyźnie, w świecie. Jest więc procesem doprowadzenia kogoś do dojrzałości osobowej, do umiejętności życia w poszanowaniu dziedzictwa ojców, do podejmowania w środowisku ludzkim odpowiedzialnych zadań, decyzji, dzieł twórczych ${ }^{30}$.

Znaczenie wychowania w życiu człowieka wyraźnie podkreśla soborowa Deklaracja o Wychowaniu Chrześcijańskim ${ }^{31}$. Dokument ten już na początku mówi o powszechnym prawie do wychowania w wierze każdego chrześcijanina i o celu, jakiemu ono służy: „Prawdziwe zaś wychowanie zdąża do kształtowania osoby ludzkiej w kierunku jej celu ostatecznego, a równocześnie do dobra społeczności” (DWCH 1). Chodzi tu o rozwijanie ,wrodzonych właściwości fizycznych, moralnych i intelektualnych" (DWCH 1). Sobór Watykański II w tejże Deklaracji podkreśla:

Wszyscy chrześcijanie, ponieważ jako nowe stworzenie dzięki odrodzeniu z wody i z Ducha Świętego, nazywają się dziećmi Bożymi i są nimi, mają prawo do wychowania chrześcijańskiego. Wychowanie to zdąża nie tylko do pełnego rozwoju osoby ludzkiej [...], lecz ma na względzie przede wszystkim to, aby ochrzczeni, wprowadzani stopniowo w tajemnicę zbawienia, stawali się z każdym dniem coraz bardziej świadomi otrzymanego daru wiary. Niechaj uczą się chwalić Boga w duchu i w prawdzie (por. J 4, 13), zwłaszcza w kulcie liturgicznym; niechaj zaprawiają się w prowadzeniu własnego życia według nowego człowieka w sprawiedliwości i świętości prawdy (Ef 4, 22-24); w ten sposób niech stają się ludźmi doskonałymi na miarę wieku pełności Chrystusowej $(E f 4,13)$ i przyczyniają się do wzrostu Ciała Mistycznego (DWCH 2).

${ }^{29}$ W. Gubała, Wychowanie moralne młodzieży, R. Murawski (red.), Teoretyczne założenia katechezy młodzieżowej, Warszawa 1989, s. 201-211.

${ }^{30}$ T. Sikorski, Wychowanie, w: A. Zuberbier (red.), Słownik teologiczny, t. 2, Katowice 1989, s. 387.

${ }^{31}$ Deklaracja o Wychowaniu Chrześcijańskim, w: Sobór Watykański II, s. 471-505 w tekście DWCH z odnośnym numerem. 
Ponadto wspomniana Deklaracja ukierunkowuje proces wychowawczy na harmonijne rozwijanie wrodzonych właściwości fizycznych, moralnych i intelektualnych. W cytowanym dokumencie wychowanie chrześcijańskie $\mathrm{z}$ jednej strony zostało włączone w wychowanie ogólne, a z drugiej - stało się fundamentem, na którym katecheza realizuje takie zadania, jak: prowadzenie do komunii z Jezusem Chrystusem, włączenie do wspólnoty Kościoła i kształtowanie postawy apostolskiej.

Wychowanie należy do podstawowych obowiązków Kościoła, który wypełnia go głównie przez katechezę. W Katechizmie Kościoła Katolickiego zapisano: „Katecheza jest wychowywaniem w wierze dzieci, młodzieży i dorosłych; obejmującym przede wszystkim wyjaśnianie nauki chrześcijańskiej, podawane na ogół w sposób systematyczny i całościowy w celu wprowadzenia wierzących w pełnię życia chrześcijańskiego" (KKK 5, por. CT 18$)^{32}$.

Zagadnienie wychowania dzieci i młodzieży było istotnym problemem wszystkich minionych pokoleń, podobnie jest i dzisiaj. Jednak obecnie

odnosi się wrażenie, że nasze czasy nie sprzyjają promowaniu idei wychowawczych. Z jednej strony świat przeżywa fascynację technicznymi możliwościami współczesnej cywilizacji i elektronicznych mediów budujących nowy porządek informacji, a z drugiej strony - odnotowujemy przerażającą degradację duchowego środowiska człowieka powodowaną przez konsumpcyjny model życia. Jeżeli dodamy do tego zgiełk politycznych kampanii, obracających się przeważnie wokół walki o władzę, może rodzić się niepokojące pytanie, czy nie zapomniano czasami o człowieku, który w tym wszystkim ma mieć udział, który tworzy, konsumuje i jednocześnie ponosi skutki cywilizacji nazywanej niekiedy cywilizacją śmierci. Czy zaniedbanie sprawy wychowania człowieka, jego formacji, nie jest zagrożeniem nie tylko kulturowym, ale i cywilizacyjnym? Czy uda się zbudować nowoczesne społeczeństwo przyszłości bez rzetelnej troski o wychowanie człowieka? ${ }^{33}$

Z całą pewnością za obecne braki w wychowaniu i właściwej formacji współczesnego człowieka wysoką cenę zapłacą przyszłe pokolenia. A nowemu społeczeństwu, żyjącemu bez właściwych wpływów wychowawczych, bez zasad i moralności, trudno wróżyć świetlaną przyszłość.

${ }^{32}$ Katechizm Kościoła katolickiego, Poznań 1984, - w tekście KKK z odnośnym numerem; Jan Paweł II, Adhortacja apostolska Catechesi Tradendae o katechizacji w naszych czasach, w: Adhortacje apostolskie Ojca Świętego Jana Pawła II, Kraków 1997, - w tekście CT z odnośnym numerem.

${ }_{33}$ J. Bagrowicz, Katecheta - chrześcijański wychowawca, w: M. Majewski (red.), Postawy katechetów, Kraków 1996, s. 46. 
Pismo Święte jednoznacznie stwierdza, że wychowawcą w pełnym tego słowa znaczeniu jest Bóg, który przez swych pośredników poucza, doświadcza z ojcowską troską i miłościa, wiedzie ludzi na drogi nawrócenia, do pełnego rozwoju duchowego i ku zbawieniu ${ }^{34}$. Pedagogia biblijna jest ujmowana w kontekście Ojciec-Syn, czyli nawiązuje do wychowania rodzinnego. Postępowanie Syna Bożego i Jego misja jest wielkim dziełem wychowawczym. Jezus, jako doskonały wychowawca, nie ogranicza się do przekazywania pouczeń, lecz gromadzi wokół siebie całe rzesze uczniów, stopniowo odsłania przed nimi Boży plan zbawienia i swoją misję mesjańską, a zarazem utożsamia się z tymi, których wychowuje, przyjmując na siebie ich słabości i oddając za nich swoje życie ${ }^{35}$.

Kościół, będąc obecny w świecie aktywnie włącza się w proces wychowawczy. Do ważnych Jego zadań wychowawczych należą: uczenie poszanowania dla każdej osoby ludzkiej $(\mathrm{ChL} 37)^{36}$, troska o zabezpieczenie każdej osobie prawa do życia (ChL 38), pobudzenie chrześcijan świeckich do zaangażowania społecznego na rzecz rodziny, inspirowanie do zaangażowania politycznego (ChL 42) oraz kształtowanie postawy służby społecznej (TMA 51) ${ }^{37}$. Wychowanie nie jest możliwe bez obecności wartości wychowawczych i obiektywnych dóbr kulturowych. „Kościół przypomina, że kulturę odnosić należy do pełnej doskonałości osoby ludzkiej, do dobra wspólnoty i całej społeczności ludzkiej. Dlatego należy tak kształtować ducha, aby rozwijała się zdolność podziwiania, wnikania w głąb, kontemplacji i urabiania sobie sądu osobistego oraz zdolność kształcenia zmysłu religijnego, moralnego i społecznego" (KDK 59).

Wskazania Kościoła określają wyraźnie także wymagania wobec wychowawców. Podstawowym jest obowiązek pracowania nad młodym człowiekiem i włączania go do współpracy, w celu doprowadzenia go do zbawienia; obowiązek pomocy w integralnym rozwoju jego osobowości oraz w odpowiedzialnym i świadomym uczestnictwie $\mathrm{w}$ życiu społecznym. W swojej posłudze nie może on zatrzymywać uwagi wychowanka na sobie. Jego posłannictwem jest ukazywanie wychowankowi wartości, celu i piękna życia chrześcijańskiego, jego roli w życiu Kościoła i powołania do świętości. Aby wychowanek mógł zrealizować to wielkie powołanie, wychowawca winien pomagać mu wzrastać $\mathrm{w}$ wierze, nadziei i miłości oraz kierować jego wolę

\footnotetext{
${ }^{34}$ Zob. Pwt 8, 5; Oz 11, 1-4.

${ }^{35}$ T. Sikorski, dz. cyt., s. 388.

${ }^{36}$ Jan Paweł II, Posynodalna adhortacja apostolska Christifideles laici o powołaniu i misji świeckich w Kościele i w świecie, Poznań 1989 (w tekście: ChL).

37 Jan Paweł II, List Apostolski Tertio Millennio Adveniente Ojca Świętego Jana Pawta II do biskupów duchowieństwa i wiernych $w$ zwiazku z przygotowaniem Jubileuszu Roku 2000, w: Wybór Listów Ojca Świętego Jana Pawła II, t. I, Kraków 1997 (w tekście TMA).
} 
ku dobru przez ukazywanie sensu życia i motywów działania. Nie wystarczy podawać wychowankowi samą tylko wiedzę, oświecać jego umysł prawdami wiary i zmuszać jego rozum do poddania się im. Trzeba równocześnie działać na serce, kształtować szlachetne uczucia miłości Boga i bliźniego, aby ta miłość stała się dla wychowanka sprężyną wszystkich jego uczućé ${ }^{8}$.

Wychowawca powinien być dla ucznia duchowym przewodnikiem. Wymaga to od niego głębokiego zrośnięcia się z prawdą i dobrem, intensywnego przeżywania wartości, które przekazuje swym wychowankom. Powinien dostrzegać w nich nie tylko osoby, ale dzieci Boga, stworzone na Jego obraz i umiłowane przez Niego. To poznanie i świadomość wielkiej godności, jaką Bóg obdarzył każdego człowieka, pomoże wychowawcy ukochać swoich uczniów, pomimo dostrzeganych słabości i błędów, cieszyć się z nimi ich sukcesami oraz spalać się w ofiarnej posłudze pedagogicznej, czerpiąc z motywów wiary pokój, równowagę, zapał apostolski, optymizm i pełne zaangażowanie ${ }^{39}$.

Powyższe refleksje wskazują, że ideał chrześcijańskiego wychowania wymaga od wychowawców odpowiedzialności, świadomości wielkości misji, do której zostali powołani i fachowego przygotowania. Aby mogli wypełnić tę misję na miarę wymagań i oczekiwań Kościoła, muszą oni być wyposażeni w niezbędne do tego dary natury i łaski. Sprawności znamionujące dobrego wychowawcę chrześcijańskiego wyrastają na gruncie jego dojrzałego charakteru moralnego. Fundament talentu pedagogicznego stanowią duchowe cechy osobowości, a więc posiadane przez niego cechy ogólnoludzkie, a szczególnie chrześcijańskie ${ }^{40}$. Wychowawca chrześcijański powinien być wymagający od siebie, opanowany, zdyscyplinowany, skoncentrowany na tym, co najważniejsze. Powinien posiadać pozytywny obraz siebie, świata i Boga. Dobry wychowawca to człowiek, który jest rozmiłowany w swoim powołaniu, wręcz identyfikujący się z otrzymaną misją, do której czuje się przez Boga posłany. Ona to całkowicie wypełnia jego świadomość, wyobraźnię i serce. Ponadto jest dla niego źródłem niegasnącej radości, mobilizuje do pełnego zaangażowania się i odpowiedniego działania. Powołanie chrześcijańskiego wychowawcy tak widziane i przeżywane staje się dla niego najważniejszą sprawą życia. Wszystkie pozostałe sprawy, nawet najważniejsze i osobiste, zostają mu całkowicie podporządkowane ${ }^{41}$.

Każdy wychowawca, jeśli traktuje ucznia jako osobę, a nie jak rzecz czy numer w dzienniku i zwraca się do niego słowami pełnymi miłości, uczy

${ }^{38} \mathrm{Cz}$. Sondej, Osobowość katechety i jej wptyw na życie katechizowanych, w: M. Śnieżyński (red.), Katecheta w szkole, Kraków 1994, s. 11.

${ }_{39}$ M. Rusiecki, Nauczycielu, kim jesteś, „Wychowawca” 10 (1993), s. 8.

40 J. Dajczak, Katechetyka, Warszawa 1956, s. 315.

${ }^{41}$ M. Rusiecki, dz. cyt., s. 8. 
miłości, uczy też szacunku do siebie i innych. Jeżeli zaś pracuje z oddaniem i zapałem - uczy pracowitości i poświęcenia ${ }^{42}$.

Od wychowawcy wymaga się, aby był on dla wychowanka wzorem osobowym, bo tylko wówczas będzie to możliwe, że ten, którego wychowuje, będzie jego „przedłużeniem”, stając się wzorem osobowym dla nowego pokolenia. Powinna zatem wychowawcę cechować nie tylko doskonałość pod względem moralnym, posiadanie autorytetu, siły pociagania innych do naśladowania, ale także powinien on wykazywać wymiar osobowy, społeczny i kulturowy ${ }^{43}$.

Należy podkreślić, że szczególnie od początku XX wieku są prowadzone żywe dyskusje na temat człowieka jako osoby. Ważne dla katolickiej koncepcji osoby są przemyślenia R. Guardiniego. Cała jego antropologia koncentruje się wokół osoby człowieka, ale jako wezwanej przez Boga. Człowiek, jako byt osoby, jest niepowtarzalny i jedyny w swoim rodzaju, wolny i panujący nad sobą i światem. Jako jednak wezwany, a raczej nieustannie wzywany przez Boga, jest zobowiązany do moralnego postępowania i odpowiedzialności za świat. Musi przy tym pamiętać, że Panem świata jest Bóg Stwórca wszystkich bytów. Człowiek, będąc bytem osobowym, ma szczególne miejsce wśród bytów stworzonych. Jego egzystencja, w przeciwieństwie do wszystkich bytów nieosobowych, jest egzystencją rozumianą jako odpowiedź. To zaś powoduje ludzką bezpośredniość w stosunku do Boga. Wolność człowieka jako bytu osobowego realizuje się jako wolność wyboru i wolność istoty. Działanie człowieka jest zawsze ukierunkowane na Boga, gdyż wezwania, jakie Bóg kieruje do niego, domagają się udzielania odpowiedzi. Jeżeli ta odpowiedź jest pozytywna (może być także negatywna), to spełnia wolę Bożą, a równocześnie urzeczywistnia siebie - swoje imię, ożywia własne «ja». Zatem - jak twierdzi dalej R. Guardini - człowiek jedynie wtedy się odnajdzie, gdy odejdzie od siebie i pójdzie tam, dokąd jest wezwany. Urzeczywistnienie osoby ludzkiej leży więc w spełnianiu woli Bożej. Jeżeli chodzi o wolność człowieka, to należy podkreślić, że człowiek dopiero jako wezwany przez Boga jest prawdziwie wolny. Wezwanie to bowiem umożliwia mu stanie się sobą, zrealizowanie swojej osobowości. Byt osobowy ma charakter daru, który musi się zrealizować w relacji do Dawcy tego daru, czyli do Boga. I w tym człowiek znajduje swoją wolność, polegającą na zrealizowaniu siebie zgodnie z wolą Boża $a^{44}$. Wzrost w doskonałości u człowieka polega na dawaniu coraz to lepszych odpowiedzi na Boże we-

${ }^{42}$ R. Sarek, Obraz katechety: nauczyciela, wychowawcy i świadka, w: J. Stala (red.), Dzisiejszy katecheta,. Kraków 2002, s. 260.

${ }^{43}$ H. Słotwińska, Wychowawcza wartość wzorów osobowych, Lublin 2008, s. 497nn.

${ }^{44}$ Zob. K. Góźdź, Teologia człowieka, Lublin 2006, s. 177-222. 
zwania, aż do stanu całkowitego podporządkowania swojej woli woli Bożej. Stąd powtarzane w Modlitwie Pańskiej wezwanie „bądź wola Twoja” nieustannie przypomina człowiekowi o konieczności ciagłego udoskonalania siebie, aż do stania się całkowitym darem dla Boga.

Człowiek będąc osoba, jednostką ludzką, jest równocześnie istotą społeczną (ens sociale). Jest, jako «ja», od początku w relacji do drugiej osoby, do «ty» i do społeczności osób. Człowiek jest świadomy siebie samego, faktu swojego życia w określonym środowisku, w konkretnej społeczności osób. Doświadcza siebie w relacjach społecznych i realizuje się w społeczności. Należy przy tym podkreślić, że pomiędzy człowiekiem a społecznością musi być równowaga. Ani społeczność nie może pochłonąć jednostki, ani jednostka nie może górować nad społecznością. Na kształtowanie tożsamości człowieka mają wpływ uwarunkowania społeczne i religijne. Na płaszczyźnie społecznej swoją tożsamość ludzką realizuje przez życie afektywne (pozytywne i negatywne), a na płaszczyźnie religijnej - w relacjach do Boga (do społeczności Osób Boskich) lub ich braku (grzech i wyobcowanie). Człowiek od strony personalnej, jako jednostka, od samego początku jest osoba, ale równocześnie w przeciagu swego życia ciągle się staje osobą jakoś dopełnia i spełnia. Według nauki chrześcijańskiej, to spełnienie się człowieka jako osoby dokonuje się przez jego pełne zjednoczenie z Chrystusem, które jest procesem trwającym w ciagu ludzkiego życia. Człowiek może jednak już za swego życia na ziemi doświadczyć swego spełnienia i całkowicie zjednoczony z Chrystusem w takim stanie przejść do wieczności ${ }^{45}$.

Człowiek żyje w świecie natury i tworzy z nią pewną jedność. Ta jedność człowieka i świata nie polega tylko na wspólnej egzystencji i wzajemnej zależności, ale obejmuje wspólne tworzenie, czyli przemianę i kształtowanie tego otoczenia, a równocześnie wychowywanie samego człowieka. Człowiek, będąc w pewnym sensie panem tego świata, ma do zrealizowania - przy współdziałaniu świata - swoje określone cele. Nie działa on jednak w pojedynkę, ale wraz z innymi ludźmi, tworząc wspólną wizję świata, w celu godnego życia zarówno jako jednostka oraz jako członek społeczności. W ten sposób jest twórcą kultury, wykorzystując istniejące pewne formy wspólnego życia, czyli instytucje, jako elementy kultury. Są nimi: szkoła, kościół, zakład pracy, zrzeszenia, kluby itp. Kształtują one świadomość sensu życia w danym porządku społecznym. Każda z określonych instytucji wyraża i kształtuje określoną świadomość sensu. Ich suma tworzy jedność kultury. Instytucje te odznaczają się trwałością, stąd i wytwarzanie sensu przez daną instytucję ma charakter trwały, który człowiek uświadamia sobie dopiero w perspektywie całego życia. Dopiero zatem w całości swego życia

${ }^{45}$ Por. tamże, s. 402-433. 
widzi on sens szkoły czy kościoła, nie identyfikując się z żadną z tych instytucji w określonym momencie historii.

Na podstawie wspólnej kultury w każdej społeczności przenikają się dwa porządki: polityczno-państwowy i religijny. Ten drugi wysuwa się na czoło, gdyż w życiu każdego człowieka odgrywa bardzo ważną rolę. Religia bowiem, oparta na mocnym fundamencie, którym jest Bóg-Stwórca wszystkiego, co istnieje, tworzy jedność światów: kosmosu i człowieka, roztaczając nad nimi uniwersalny sens całości. Kultura przez swój związek z religią ma w swoim porządku odniesienie do totalnego sensu tego świata, jakim jest Bóg. W przypadku zaś odcięcia się od religii, a tym bardziej walki z nią, traci swój uniwersalny sens ${ }^{46}$.

Chrześcijanin, troszcząc się o doskonalenie siebie, musi pamiętać, że istotą doskonałości jest miłość. Stąd wychowanie chrześcijańskie - przy „ubogacaniu świata” i korzystaniu z wszelkiego dorobku wcześniejszych pokoleń - jest wychowaniem ku pełni miłości. Jest to zatem doskonalenie się w miłości Boga, ludzi i świata. Tego rodzaju doskonaleniu służy życie modlitewne, sakramentalne i wypełnianie obowiązków stanu, ale istotą doskonalenia pozostaje zawsze miłość. Wszystko zaś inne o tyle służy doskonaleniu się - jak to podkreśla św. Paweł w swoim Hymnie o miłości (por. 1 Kor 13,1-13) - o ile staje się funkcją miłości.

Należy podkreślić, że doskonałość ma charakter dynamiczny i podlega prawu ustawicznego urzeczywistniania się. Tradycyjnie wyróżnia się trzy stopnie doskonałości: (1) oczyszczenie (stopień początkujących), polegające na walce z grzechem i złymi pożądaniami sprzecznymi z powinnością miłości, (2) oświecenie (stopień postępujących) - ćwiczenie się w cnotach i we wszelkim dobru, polegające na doskonaleniu się w miłości i (3) zjednoczenie (stopień doskonałych) - polega na zjednoczeniu się z Bogiem i całym Bożym stworzeniem w doskonałej miłości. Oprócz tego podziału wyróżnia się także ascetyczny i mistyczny poziom doskonałości chrześcijańskiej, można również mówić o stopniach doskonałości, przyjmując jako kryterium podziału stadia miłości. Przy tym ważna jest prawda, że doskonałość chrześcijańską osiaga się na bazie doskonałości ludzkiej (Gratia non tollit naturam, sed supponit et perfecit eam). Stąd, chrześcijanin powinien sięgać po wszystkie naturalne środki rozwoju swego człowieczeństwa, a następnie odwoływać się do tych mocy, które płyną z łaski dającej wzrost szczególnie w życiu modlitewno-sakramentalnym ${ }^{47}$.

${ }^{46}$ Por. tamże, s. 434-482.

${ }^{47}$ W. Słomka, H. Wejman, Doskonałość, w: M. Chmielewski (red.), Leksykon Duchowości Katolickiej, Lublin-Kraków 2002, s. 214-217. 
Podsumowując należy stwierdzić, że człowiek wraz z powołaniem go do istnienia został powołany na twórcę kultury. Niniejsze powołanie realizuje poprzez udoskonalanie zarówno świata, w którym żyje, jak i samego siebie. Chrześcijanin, zdając sobie sprawę z tego, że istotą doskonałości jest miłość, powinien traktować swoje życie jako wzrastanie w miłości do Boga, do ludzi i do świata. Ponadto ważne jest, by miał świadomość, że doskonałość chrześcijańską należy budować na doskonałości ludzkiej, ponieważ łaska nie znosi natury, ale ją zakłada i udoskonala.

\section{The Role of Culture in Christian Education (Summary)}

The article touches upon five issues. Its opening section expounds in detail on multifarious aspects of the notion of culture. In the following sections culture is shown as a vehicle by means of which the world and culture itself can be perfected. Moreover, the article depicts the relationship between God's message of salvation, on the one hand, and culture, on the other. The final section explores links involving Christian education and culture.

The article indicates that having been called into existence man was also called to become a creator of culture. Men and women pursue this calling through perfecting themselves and the world around. While realizing the fact that love is the essence of perfection, a Christian ought to perceive his life in terms of growth in the spirit of love towards God, people and the world. 